\title{
Research Article \\ EFFECT OF DIFFERENT IRRIGATION REGIMES AND FERTIGATION LEVELS ON YIELD OF TOMATO UNDER NATURALLY-VENTILATED POLYHOUSE AND OPEN FIELD
}

\author{
WANKHEDE P.S. , DAHIWALKAR S.D., GORANTIWAR S.D. AND GAIKAWAD M.A.
}

Department of Irrigation and Drainage Engineering, Mahatma Phule Krishi Vidyapeeth, Rahuri, Ahmednagar, 413722, Maharashtra

*Corresponding Author: Email-wankhede_pranu@rediffmail.com

Received:December 02, 2016; Revised: January 25, 2018; Accepted: January 26, 2018; Published: February 28, 2018

\begin{abstract}
The experiment was conducted to evaluate the yield response of tomato (Solanum lycopersicum L.) to different irrigation regimes and fertigation levels under polyhouse and open field conditions. The treatment consisted of three irrigation regimes $0.95 \mathrm{ETC}, 0.70 \mathrm{ETC}$, and $0.45 \mathrm{ETc}$. and three fertigation levels $125 \% \mathrm{RD}, 100$ $\% \mathrm{RD}$ and $75 \% \mathrm{RD}$. The experimental design was split plot with six replications. The biometric attribute plant height was measured at harvest condition and yield attribute viz., average weight of fruit, yield in $\mathrm{kg}$ per plant, $\mathrm{kg} \mathrm{per} \mathrm{m}^{2}$ and yield in tha. It is seen from the data pooled over two years that the plant height of tomato under polyhouse and open field was maximum $(240.5 \mathrm{~cm}$ and $133.9 \mathrm{~cm})$ due to $0.95 \mathrm{ETc}\left(\mathrm{l}_{1}\right)$ irrigation level over other irrigation levels. Data on plant height was not significant. The minimum plant height was found in $0.45 \mathrm{ETc}\left(\mathrm{l}_{3}\right)$. It is seen from the data pooled over two years that the fertigation level $125 \%$ RD $\left(\mathrm{F}_{1}\right)$ recorded the maximum and not significant plant height $(227.81$ and $128.86 \mathrm{~cm}$ ) under polyhouse and open field over other fertigation levels. The pooled data show that the average weight of a fruit of tomato was maximum $(123.83 \mathrm{~g})$ due to 0.95 ETc irrigation level over other irrigation levels. It was at par with all irrigation levels. Irrigation level of $0.45 \mathrm{ETc}$ recorded minimum fruit weight of tomato under polyhouse condition. Data on effect of different irrigation levels on average weight of fruit of tomato were statistically not

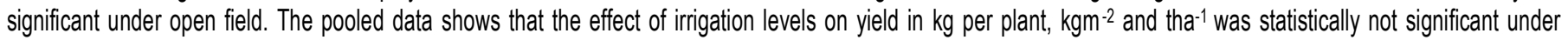
polyhouse and open field. The pooled data shows that the effect of fertigation levels on yield in $\mathrm{kg}$ per plant, $\mathrm{kgm}^{-2}$ and tha-1 was not significant under polyhouse and open field. The average water use efficiency of tomato was in the range of 49.23 to $71.27 \mathrm{~kg} / \mathrm{m}^{2}-\mathrm{m}^{-1}$ and 13.55 to $31.15 \mathrm{~kg} / \mathrm{m}^{2}-\mathrm{m}^{-1}$ under polyhouse and open field conditions.
\end{abstract}

Keywords- drip irrigation, fertigation and water use efficiency.

Citation: Wankhede P. S., et al., (2018) Effect of Different Irrigation Regimes and Fertigation Levels on Yield of Tomato under Naturally-Ventilated Polyhouse and Open Field. International Journal of Agriculture Sciences, ISSN: 0975-3710 \& E-ISSN: 0975-9107, Volume 10, Issue 4, pp.-5207-5211.

Copyright: Copyright@2018 Wankhede P. S., et al., This is an open-access article distributed under the terms of the Creative Commons Attribution License, which permits unrestricted use, distribution and reproduction in any medium, provided the original author and source are credited.

Academic Editor / Reviewer: Panjavarnam G, Bhavishya

\section{Introduction}

Tomato is a warm season plant. It can withstand with severe frost conditions. Temperature and light intensity affect germination, vegetative growth, fruit set, pigmentation and nutritive value of this fruits. The minimum temperature for germination of seeds range from 80 to $10^{\circ} \mathrm{C}$. The night temperature is the critical factor in fruit setting with the optimum range of $160^{\circ} \mathrm{C}$ to $22^{\circ} \mathrm{C}$. Fruits fail to set at $12^{\circ} \mathrm{C}$ or below. Under greenhouse conditions tomato crop can grow for long duration (10-12 months) by cooling during summer months (April to June or July) and by heating the greenhouse during peak winter months (December and January) in northern parts of the country [6]. Creating high values for agricultural crops by using low water inputs and high fertilizer efficiencies is one of the methods used in addressing the environmental and resources problems. Protected cultivation techniques including nethouse technology provide optimum environmental medium for better crop growth in order to gain maximum yield and high-quality products. These require comparatively less land area for agricultural production system resulting in increased land productivity and facilitate year-round production of crops. Many studies were reported on tomato cultivation under green/nethouse conditions with different advantages ref as [3].

\section{Materials and Methods}

The field experiment was conducted at the Instructional Farm of Department of Irrigation and Drainage Engineering, Dr. Annasaheb Shinde College of Agricultural
Engineering and Technology, Mahatma Phule Krishi Vidyapeeth, Rahuri during the period from November 2013 to May 2014 and November 2014 to May 2015. Geographically the farm lies at $74038^{\prime} 00^{\prime \prime} E$ longitudes and $19020^{\prime} 00^{\prime \prime} N$ latitude at $557 \mathrm{~m}$ above the mean sea levels in the central campus of Mahatma Phule Krishi Vidyapeeth, Rahuri.

\section{Climatological data}

The meteorological data on maximum and minimum temperature, minimum and maximum relative humidity, actual sunshine hour and daily wind speed etc. weather parameter during the crop growth period (30 November 2013 to $5^{\text {th }}$ May 2014) and (1 December 2014 to $5^{\text {th }}$ May 2015) were collected on daily basis from the meteorological observatory situated at the Instructional Farm of Department of Irrigation and Drainage Engineering, Mahatma Phule Krishi Vidyapeeth, Rahuri.

Water source The water for the experiment was pumped from an open dug well situated at the Instructional Farm of Department of Irrigation and Drainage Engineering.

\section{Experimental Details}

Two experiments were conducted under this investigation for two consecutive years. The details are given below.

Response of tomato to irrigation regimes and fertigation levels under polyhouse 
condition and open field conditions. Two experiments was conducted under this investigation for two consecutive years. This experiment was carried out in split plot design with nine treatments based on different combinations of the irrigation levels and fertigation levels. Crop verity was Hy. Phule Raja. Plot size was $2.7 \mathrm{mX}$ $1 \mathrm{~m}$ and plant spacing was $60 \mathrm{~cm} \times 45 \mathrm{~cm}$. Number of plants per bed was 12 . The area of polyhouse and open field was $25 \mathrm{~m} \times 20 \mathrm{~m}$. The soil media in polyhouse consisted of red soil, farm yard manure (FYM) and sand. Irrigation was given at daily basis over the whole crop period of tomato by drip irrigation method. And fertigation was given at an alternate day. The fogger system had automatic controller to operate the system for 30 second ('ON' period) after the interval of ('OFF' period) period about 8 minutes. Fogger system was operating at 2-2.5 $\mathrm{kg} / \mathrm{cm}^{2}$.

\section{Treatment Details}

$\begin{array}{lll}\text { Sr. } & \text { Factor } A \text { : Shading percentage } & \begin{array}{l}\text { Factor } B: \text { Irrigation } \\ \text { levels }\end{array} \\ \text { No. } & & F_{1}=125 \% \mathrm{RD} \\ 1 & l_{1}=0.95 \mathrm{ETC} & \mathrm{F}_{2}=100 \% \mathrm{RD} \\ 2 & l_{2}=0.70 \mathrm{ETC} & \mathrm{F}_{3}=75 \% \mathrm{RD}\end{array}$

In order to study the response of tomato to irrigation regimes and fertigation levels under polyhouse and open field condition, it was necessary to collect data on the plant and yield attributes of the tomato crop. These data were collected during the experimental period and analyzed further for interpretations. The crop growth parameters including plant height were recorded at harvest condition with 5 randomly selected plants from each plot. These plants were properly labeled and growth parameters were monitored on them. The observations include average weight of tomato fruit, total yield of tomato fruit. The water use efficiency for each treatment was determined from the data on corresponding yield and volume of water applied using the following equation:

$$
W U E=\frac{\sum Y}{W R}
$$

Where, WUE $=$ Water use efficiency $($ t/ha-cm)

$Y=$ Yield of crop product (t/ha), WR = Total depth of water applied in the field $(\mathrm{cm})$ In order to compare the treatments of different shading percentages with irrigation levels separate analysis split plot design was prepared.

\section{Result and Discussion}

The field investigation was carried out to compare the growth and yield attributing characteristics, water saving and water use efficiency under different irrigation levels and fertigation levels. The growth and yield characteristics of tomato were periodically monitored and recorded during the crop growth period.

Plant height: It is seen from the data pooled over two years that the plant height of tomato under polyhouse and open field was maximum $(240.5 \mathrm{~cm}$ and $133.9 \mathrm{~cm})$ due to $0.95 \mathrm{ETc}\left(\mathrm{l}_{1}\right)$ irrigation level over other irrigation levels. Data on plant height was not significant. The minimum plant height was found in $0.45 \mathrm{ETc}\left(\mathrm{I}_{3}\right)$ these are presented in [Table-1]. It is seen from the data pooled over two years that the fertigation level $125 \% \mathrm{RD}\left(\mathrm{F}_{1}\right)$ recorded the maximum and not significant plant height $(227.81$ and $128.86 \mathrm{~cm})$ under polyhouse and open field over other fertigation levels as presented in [Table-1]. Heights of plant were significantly influenced by different levels of $\mathrm{N}$ and $\mathrm{K}$ fertigation. Better growth of plant height due to increasing fertigation levels as compared to the conventional fertilization. Highest plant heights $(146.10 \mathrm{~cm})$ were recorded in $100 \%$ fertigation of RD of $\mathrm{N}$ and $\mathrm{K}$, whereas conventional fertilization recorded the minimum plant height $(110.63 \mathrm{~cm})$. Positive effect of fertigation on plant height of tomato grown inside polyhouse. Ref as [4]. The interaction of both the factors in respect of plant height was not significant.

\section{Yield Characteristics:}

The pooled data show that the average weight of a fruit of tomato was maximum $(123.83 \mathrm{~g})$ due to $0.95 \mathrm{ETc}$ irrigation level over other irrigation levels. It was at par with all irrigation levels. Irrigation level of $0.45 \mathrm{ETc}$ recorded minimum fruit weight of tomato under polyhouse condition. Data on effect of different irrigation levels on average weight of fruit of tomato were statistically not significant under open field are presented in [Table-2]. The interaction of both the factors in respect of average weight a fruit was significantly influenced. It was found that the interactions of $0.95 \% \mathrm{ETC} \times 100 \% \mathrm{RD}\left(\mathrm{l}_{1} \times \mathrm{F}_{2}\right)$ recorded the maximum average weight of fruit (125.68 g) which was at par of all interaction except 0.45 ETc $\times 75$ $\% \mathrm{RD}\left(\mathrm{l}_{3} \times \mathrm{F}_{3}\right)$ under polyhouse conditions these are presented in [Table-3]. Tomato plant grown under polyhouse was observed to be earlier in flowering and fruit setting by about 3 and 5 days, respectively when compared to the crop raised under open field conditions. The early and higher fruit weight and yield of tomato crops inside polyhouse was mainly because of better microclimate than the open field observed during winter months. Therefore, the polyhouse environment may provide a new scope for commercial production of high value vegetable crops like tomato. Ref as [3].

Table-1 Plant height of tomato at harvest as affected by different treatments for the year 2013-14, 2014-15 and pooled under polyhouse and open field.

\begin{tabular}{|c|c|c|c|c|c|c|}
\hline \multirow[t]{3}{*}{ Treatments } & \multicolumn{6}{|c|}{ Plant height cm (At harvest) } \\
\hline & \multicolumn{3}{|c|}{ Poly house } & \multicolumn{3}{|c|}{ Open field } \\
\hline & 2013-14 & 2014-15 & Pooled & 2013-14 & $2014-15$ & Pooled \\
\hline \multicolumn{7}{|c|}{ A. Irrigation level (I) } \\
\hline$l_{1}=0.95 \mathrm{ETC}$ & 223.56 & 257.44 & 240.5 & 124.17 & 143.78 & 133.97 \\
\hline$l_{2}=0.70 \mathrm{ETC}$ & 205.06 & 236.22 & 222.64 & 115.00 & 135.78 & 125.39 \\
\hline$I_{3}=0.45 \mathrm{ETC}$ & 192.44 & 216.94 & 204.69 & 107.89 & 125.78 & 116.83 \\
\hline S.E. \pm & 2.09 & 2.22 & 1.62 & 1.87 & 3.31 & 1.82 \\
\hline C.D. at 5\% & 6.61 & 7.003 & NS & 5.90 & 10.44 & NS \\
\hline \multicolumn{7}{|c|}{ B. Fertigation level (F) } \\
\hline$F_{1}=125 \% R D$ & 211.56 & 244.06 & 227.81 & 118.33 & 139.39 & 128.86 \\
\hline $\mathrm{F}_{2}=100 \% \mathrm{RD}$ & 207.78 & 237.11 & 222.44 & 115.39 & 133.83 & 124.61 \\
\hline $\mathrm{F}_{3}=75 \% \mathrm{RD}$ & 201.72 & 229.44 & 215.58 & 113.33 & 132.11 & 122.72 \\
\hline S.E. \pm & 1.91 & 1.90 & 1.34 & 1.83 & 1.80 & 1.26 \\
\hline C.D. at $5 \%$ & 5.51 & 5.50 & NS & NS & 5.21 & NS \\
\hline \multicolumn{7}{|c|}{ C. Interaction (IxF) } \\
\hline S.E. \pm & 5.01 & 5.04 & 2.44 & 4.72 & 5.26 & 2.13 \\
\hline C.D. at $5 \%$ & NS & 10.94 & NS & NS & NS & NS \\
\hline
\end{tabular}


Wankhede P. S., Dahiwalkar S. D., Gorantiwar S. D. and Gaikawad M.A.

Table-2 Average weight of a fruit as affected by different treatments for the year 2013-14, 2014-15 and pooled means under polyhouse and open field.

\begin{tabular}{|c|c|c|c|c|c|c|}
\hline \multirow[t]{3}{*}{ Treatments } & \multicolumn{6}{|c|}{ Average weight of a fruit, $(\mathrm{g})$} \\
\hline & \multicolumn{3}{|c|}{ Poly house } & \multicolumn{3}{|c|}{ Open field } \\
\hline & 2013-14 & $2014-15$ & Pooled & 2013-14 & $2014-15$ & Pooled \\
\hline \multicolumn{7}{|c|}{ A. Irrigation level (I) } \\
\hline$I_{1}=0.95 \mathrm{ETC}$ & 117.53 & 130.14 & 123.83 & 88.08 & 81.53 & 84.80 \\
\hline $\mathrm{I}_{2}=0.70 \mathrm{ETC}$ & 111.01 & 94.27 & 102.64 & 72.97 & 64.57 & 68.77 \\
\hline$I_{3}=0.45 \mathrm{ETC}$ & 107.28 & 64.55 & 85.91 & 63.03 & 50.58 & 56.80 \\
\hline S.E. \pm & 2.273 & 3.713 & 13.84 & 1.232 & 1.286 & 0.95 \\
\hline C.D. at $5 \%$ & 7.163 & 11.69 & 41.52 & 3.881 & 3.99 & NS \\
\hline \multicolumn{7}{|c|}{ B. Fertigation level (F) } \\
\hline$F_{1}=125 \% R D$ & 114.08 & 104.0 & 109.07 & 78.86 & 72.95 & 75.90 \\
\hline $\mathrm{F}_{2}=100 \% \mathrm{RD}$ & 112.20 & 97.10 & 104.65 & 75.09 & 66.87 & 70.98 \\
\hline$F_{3}=75 \%$ RD & 109.54 & 87.80 & 98.67 & 70.13 & 56.86 & 63.49 \\
\hline S.E. \pm & 2.216 & 3.162 & 1.97 & 2.202 & 2.188 & 1.56 \\
\hline C.D. at $5 \%$ & NS & 9.131 & NS & 6.36 & 6.31 & NS \\
\hline \multicolumn{7}{|c|}{ C. Interaction (IXF) } \\
\hline S.E. \pm & 5.774 & 8.385 & 12.31 & 5.499 & 5.47 & 2.72 \\
\hline C.D. at $5 \%$ & NS & NS & 40.15 & NS & 11.39 & NS \\
\hline
\end{tabular}

Table-3 Interaction effect of irrigation and fertigation levels on fruit weight $(g)$ of tomato under polyhouse condition.

\begin{tabular}{|c|c|c|c|c|}
\hline \multirow{2}{*}{ Fertigation levels $(\mathbf{F})$} & \multicolumn{4}{|c|}{ Irrigation levels $(\mathrm{I})$} \\
\cline { 2 - 5 } & $\mathrm{l}_{1}=0.95 \mathrm{ETc}$ & $\mathrm{l}_{2}=0.70 \mathrm{ETc}$ & $\mathrm{l}_{3}=0.45 \mathrm{ETc}$ & Mean \\
\hline $\mathrm{F}_{1}=125 \% \mathrm{RD}$ & 122.77 & 111.25 & 93.185 & 109.07 \\
\hline $\mathrm{F}_{2}=100 \% \mathrm{RD}$ & 125.68 & 102.43 & 85.83 & 104.65 \\
\hline $\mathrm{F}_{3}=75 \% \mathrm{RD}$ & 123.05 & 94.24 & 78.72 & 98.67 \\
\hline Mean & 123.83 & 102.64 & 85.91 & 104.13 \\
\hline $\mathrm{I} \times \mathrm{FF}$ & \multicolumn{4}{|c|}{ S.E. $=12.31$, C.D. at $5 \%=40.15$} \\
\hline
\end{tabular}

The pooled data shows that the effect of irrigation levels on yield in kg per plant, $\mathrm{kgm}^{-2}$ and tha-1 was statistically not significant under polyhouse and open field. The pooled data shows that the effect of fertigation levels on yield in $\mathrm{kg}$ per plant, $\mathrm{kgm}^{-2}$ and tha-1 was not significant under polyhouse and open field. Different fertigation treatments $100 \% \mathrm{RD}$ of $\mathrm{N}$ and $\mathrm{K}$ recorded the highest yield attributes and marketable fruit yield (122.59 t/ha) of tomato compared to $75 \%$ and $50 \%$ levels of fertigation and significantly superior to the conventional fertilization (control). Results revealed that marketable fruit yield between $50 \%$ fertigation levels and conventional fertilization were at par indicating that fertigation saved fertilizers to the tune of $50 \%$ as compared to the conventional control. It was concluded from the study that drip fulfilment at 100\% ER with $100 \%$ supplementation of $\mathrm{RD}$ of $\mathrm{N}$ was found to be beneficial for higher growth, yield, quality of tomato grown inside naturally ventilated polyhouse under the agroclimatic conditions. Ref as [2]. The interaction of $0.95 E T c \times 125 \% R D\left(l_{1} \times F_{1}\right)$ was maximum yield in $\mathrm{kg}$ per plant (8.04) and significantly superior to the other interactions under polyhouse conditions. The interaction effect on yield in $\mathrm{kgm}^{-2}$ and tha-1 was not significant under polyhouse and open field as presented in [Table-4,5,6 and 7].

Table-4 Fruit yield of tomato ( kgplant ${ }^{-1}$ ) as affected by different treatments for the year 2013-14, 2014-15 and pooled means under polyhouse and open field conditions.

\begin{tabular}{|c|c|c|c|c|c|c|}
\hline \multirow[t]{3}{*}{ Treatments } & \multicolumn{3}{|c|}{ Polyhouse } & \multicolumn{3}{|c|}{ Open field } \\
\hline & \multicolumn{3}{|c|}{ Yield, kg plant-1 } & \multicolumn{3}{|c|}{ Yield, kg plant-1 } \\
\hline & $2013-14$ & $2014-15$ & Pooled & $2013-14$ & $2014-15$ & Pooled \\
\hline \multicolumn{7}{|c|}{ A. Irrigation level (I) } \\
\hline$l_{1}=0.95 E T C$ & 6.60 & 7.10 & 6.85 & 2.05 & 2.16 & 2.10 \\
\hline $\mathrm{I}_{2}=0.70 \mathrm{ETC}$ & 3.93 & 3.82 & 3.87 & 1.26 & 1.28 & 1.27 \\
\hline$l_{3}=0.45 \mathrm{ETC}$ & 2.48 & 1.91 & 2.19 & 0.86 & 0.81 & 0.83 \\
\hline S.E. \pm & 0.28 & 0.23 & 0.19 & 0.076 & 0.070 & 5.05 \\
\hline C.D. at $5 \%$ & 0.88 & 0.73 & NS & 0.239 & 0.22 & NS \\
\hline \multicolumn{7}{|c|}{ B. Fertigation level (F) } \\
\hline$F_{1}=125 \%$ RD & 5.11 & 5.15 & 5.13 & 1.61 & 1.68 & 1.64 \\
\hline$F_{2}=100 \% R D$ & 4.27 & 4.23 & 4.25 & 1.37 & 1.37 & 1.37 \\
\hline $\mathrm{F}_{3}=75 \% \mathrm{RD}$ & 3.62 & 3.45 & 3.53 & 1.19 & 1.20 & 1.19 \\
\hline S.E. \pm & 0.137 & 0.046 & 4.35 & 0.069 & 0.064 & 0.046 \\
\hline C.D. at $5 \%$ & 0.396 & 0.133 & NS & 0.199 & 0.186 & NS \\
\hline \multicolumn{7}{|c|}{ C. Interaction (IxF) } \\
\hline S.E. \pm & 0.414 & 0.231 & 0.24 & 0.181 & 0.169 & 7.82 \\
\hline C.D. at $5 \%$ & NS & 0.556 & 0.73 & NS & NS & NS \\
\hline
\end{tabular}


Effect of Different Irrigation Regimes and Fertigation Levels on Yield of Tomato under Naturally-Ventilated Polyhouse and Open Field

Table-5 Interaction effect of irrigation and fertigation levels on yield (kgplant $\left.{ }^{-1}\right)$ of tomato under polyhouse condition

\begin{tabular}{|c|c|c|c|c|}
\hline \multirow[t]{2}{*}{ Fertigation levels (F) } & \multicolumn{4}{|c|}{ Irrigation levels (I) } \\
\hline & $\mathrm{h}_{\mathrm{h}}=0.95 \mathrm{ETC}$ & $l_{2}=0.70 \mathrm{ETC}$ & $\mathrm{l}_{3}=0.45 \mathrm{ETC}$ & Mean \\
\hline$F_{1}=125 \%$ RD & 8.04 & 4.76 & 2.58 & 5.13 \\
\hline$F_{2}=100 \%$ RD & 6.81 & 3.76 & 2.17 & 4.25 \\
\hline$F_{3}=75 \% R D$ & 5.68 & 3.1 & 1.81 & 3.53 \\
\hline Mean & 6.85 & 3.87 & 2.19 & 4.30 \\
\hline IXF & \multicolumn{4}{|c|}{ S.E. $\pm=0.24$, C.D. at $5 \%=0.73$} \\
\hline
\end{tabular}

Table-6 Fruit yield of tomato ( $\left.\mathrm{kgm}^{-2}\right)$ as affected by different treatments for the year 2013-14, 2014-15 and pooled means under polyhouse and open field.

\begin{tabular}{|c|c|c|c|c|c|c|}
\hline \multirow{2}{*}{ Treatments } & \multicolumn{3}{|c|}{$\begin{array}{l}\text { Polyhouse } \\
\mathrm{kg} \mathrm{m}^{-2}\end{array}$} & \multirow{2}{*}{\multicolumn{3}{|c|}{$\begin{array}{l}\text { Open field } \\
\mathrm{kg} \mathrm{m}^{-2}\end{array}$}} \\
\hline & $2013-14$ & 2014-15 & Pooled & & $2014-15$ & Pooled \\
\hline \multicolumn{7}{|c|}{ A. Irrigation level (I) } \\
\hline$I_{1}=0.95 \mathrm{ETC}$ & 37.91 & 38.54 & 38.22 & 12.64 & 12.77 & 12.70 \\
\hline $\mathrm{I}_{2}=0.70 \mathrm{ETC}$ & 26.36 & 26.22 & 26.29 & 7.45 & 7.48 & 7.46 \\
\hline$I_{3}=0.45 \mathrm{ETC}$ & 17.54 & 16.83 & 17.18 & 4.10 & 4.04 & 4.07 \\
\hline S.E. \pm & 1.327 & 1.23 & 0.87 & 0.151 & 0.161 & 0.10 \\
\hline C.D. at $5 \%$ & 4.18 & 3.89 & NS & 0.475 & 0.48 & NS \\
\hline \multicolumn{7}{|c|}{ B. Fertigation level (F) } \\
\hline$F_{1}=125 \% R D$ & 31.19 & 31.23 & 31.21 & 9.60 & 9.69 & 9.64 \\
\hline $\mathrm{F}_{2}=100 \% \mathrm{RD}$ & 27.01 & 26.96 & 26.98 & 7.89 & 7.90 & 7.89 \\
\hline$F_{3}=75 \% R D$ & 23.62 & 23.40 & 23.51 & 6.70 & 6.71 & 6.70 \\
\hline S.E. \pm & 0.56 & 0.52 & 0.37 & 0.216 & 0.21 & 0.14 \\
\hline C.D. at $5 \%$ & 1.637 & 1.50 & NS & 0.625 & 0.61 & NS \\
\hline \multicolumn{7}{|c|}{ C. Interaction (IxF) } \\
\hline S.E. \pm & 1.80 & 1.66 & 0.63 & 0.546 & 0.36 & 0.24 \\
\hline C.D. at 5\% & NS & NS & NS & 1.14 & 1.06 & NS \\
\hline
\end{tabular}

Table-7 Fruit yield of tomato ( h $^{-1}{ }^{-1}$ ) as affected by different treatments for the year 2013-14, 2014-15 and pooled means under polyhouse and open field condition.

\begin{tabular}{|c|c|c|c|c|c|c|}
\hline \multirow{3}{*}{ Treatments } & \multicolumn{3}{|c|}{ Polyhouse } & \multicolumn{3}{|c|}{ Open field } \\
\hline & \multicolumn{3}{|c|}{ Yield , tha-1 } & \multicolumn{3}{|c|}{ Yield , tha-1 } \\
\hline & 2013-114 & $2014-15$ & Pooled & 2013-14 & $2014-15$ & Pooled \\
\hline \multicolumn{7}{|c|}{ A. Irrigation level (I) } \\
\hline$l_{1}=0.95 E T c$ & 379.15 & 385.39 & 382.27 & 126.39 & 127.72 & 127.05 \\
\hline $\mathrm{I}_{2}=0.70 \mathrm{ETC}$ & 263.60 & 262.21 & 262.90 & 74.49 & 74.77 & 74.63 \\
\hline$I_{3}=0.45 \mathrm{ETC}$ & 175.37 & 168.27 & 171.82 & 41.00 & 40.44 & 40.72 \\
\hline S.E. \pm & 13.27 & 12.35 & 8.70 & 1.50 & 1.61 & 1.06 \\
\hline C.D. at $5 \%$ & 41.82 & 38.91 & NS & 4.75 & 4.83 & NS \\
\hline \multicolumn{7}{|c|}{ B. Fertigation level (F) } \\
\hline$F_{1}=125 \% R D$ & 311.87 & 312.31 & 312.09 & 96.02 & 96.86 & 96.44 \\
\hline$F_{2}=100 \% R D$ & 270.08 & 269.58 & 269.83 & 78.89 & 78.95 & 78.92 \\
\hline$F_{3}=75 \% R D$ & 236.17 & 233.97 & 235.07 & 66.97 & 67.11 & 67.04 \\
\hline S.E. \pm & 5.66 & 5.21 & 3.79 & 2.16 & 2.13 & 1.49 \\
\hline C.D. at $5 \%$ & 16.37 & 15.06 & NS & 6.24 & 6.39 & NS \\
\hline \multicolumn{7}{|c|}{ C. Interaction (IXF) } \\
\hline S.E. \pm & 18.02 & 9.03 & 6.34 & 5.45 & 3.69 & 2.47 \\
\hline C.D. at $5 \%$ & NS & NS & NS & 11.45 & 10.65 & NS \\
\hline
\end{tabular}

Table-8 Average water use efficiency of tomato under different treatments of irrigation and fertigation levels under polyhouse condition.

\begin{tabular}{|c|c|c|c|c|c|c|}
\hline \multirow[t]{2}{*}{ Treatments } & \multicolumn{3}{|c|}{ Yield, $\mathrm{kg} \mathrm{m}^{-2}$} & \multicolumn{3}{|c|}{ WUE, $\mathrm{kg} / \mathrm{m}^{-2}-\mathrm{m}^{-1}$} \\
\hline & 2013-14 & $2014-15$ & Average & 2013-14 & 2014-15 & Average \\
\hline $\mathrm{I}_{1} \times F_{1}(0.95 \mathrm{ET} \times 125 \% \mathrm{RD})$ & 43.43 & 44.17 & 43.80 & 81.86 & 60.67 & 71.27 \\
\hline $\mathrm{l}_{1} \mathrm{x} \mathrm{F}_{2}(0.95 \mathrm{ETc} \times 100 \% \mathrm{RD})$ & 37.14 & 37.81 & 37.48 & 69.99 & 51.94 & 60.97 \\
\hline $\mathrm{l}_{1} \times \mathrm{F}_{3}(0.95 \mathrm{ETc} \times 75 \% \mathrm{RD})$ & 33.17 & 33.64 & 33.41 & 62.52 & 46.21 & 54.37 \\
\hline $\mathrm{I}_{2} \times \mathrm{F}_{1}(0.70 \mathrm{ETc} \times 125 \% \mathrm{RD})$ & 29.53 & 29.58 & 29.56 & 75.52 & 55.15 & 65.34 \\
\hline $\mathrm{l}_{2 \times F_{2}}(0.70 \mathrm{ETC} \times 100 \%$ RD) & 26.51 & 26.39 & 26.45 & 67.81 & 49.21 & 58.51 \\
\hline $\mathrm{I}_{2} \mathrm{XF}_{3}(0.70 \mathrm{ETc} \times 75 \% \mathrm{RD})$ & 23.04 & 22.69 & 22.87 & 58.92 & 42.30 & 50.61 \\
\hline $\mathrm{I}_{3} \mathrm{XF}_{1}(0.45 \mathrm{ETc} \times 125 \% \mathrm{RD})$ & 20.6 & 19.95 & 20.28 & 81.97 & 57.86 & 69.92 \\
\hline $\mathrm{I}_{3} \times \mathrm{F}_{2}(0.45 \mathrm{ETC} \times 100 \% \mathrm{RD})$ & 17.37 & 16.67 & 17.02 & 69.13 & 48.35 & 58.74 \\
\hline $\mathrm{I}_{3} \mathrm{XF}_{3}(0.45 \mathrm{ETc} \times 75 \% \mathrm{RD})$ & 14.64 & 13.86 & 14.25 & 58.25 & 40.21 & 49.23 \\
\hline
\end{tabular}


Water use efficiency under polyhouse and open field: The average water use efficiency of tomato was in the range of 49.23 to $71.27 \mathrm{~kg} / \mathrm{m}^{2}-\mathrm{m}^{-1}$ and13.55 to
$31.15 \mathrm{~kg} / \mathrm{m}^{2}-\mathrm{m}^{-1}$ under polyhouse and open field conditions as presented in [Table-8] and [Table-9].

\begin{tabular}{|c|c|c|c|c|c|c|}
\hline \multirow[t]{2}{*}{ Treatments } & \multicolumn{3}{|c|}{ Yield, $\mathrm{kg} \mathrm{m}^{-2}$} & \multicolumn{3}{|c|}{ WUE, $\mathrm{kg} / \mathrm{m}^{-2}-\mathrm{m}^{-1}$} \\
\hline & 2013-14 & 2014-15 & Average & 2013-14 & 2014-15 & Average \\
\hline$l_{1} \times F_{1}(0.95 E T c x 125 \% R D)$ & 14.86 & 15.14 & 15.00 & 31.63 & 30.66 & 31.15 \\
\hline $\mathrm{l}_{1} \times F_{2}(0.95 \mathrm{ETC} \times 100 \% \mathrm{RD})$ & 12.42 & 12.49 & 12.46 & 26.44 & 25.30 & 25.87 \\
\hline $\mathrm{l}_{1} \times \mathrm{F}_{3}(0.95 \mathrm{ETc} \times 75 \% \mathrm{RD})$ & 10.6 & 10.69 & 10.65 & 22.56 & 21.65 & 22.11 \\
\hline $\mathrm{I}_{2} \mathrm{~F}_{1}(0.70 \mathrm{ETC} \times 125 \% \mathrm{RD})$ & 8.87 & 8.91 & 8.89 & 25.21 & 24.08 & 24.65 \\
\hline $\mathrm{I}_{2} \mathrm{XF}_{2}(0.70 \mathrm{ETC} \times 100 \% \mathrm{RD})$ & 7.27 & 7.30 & 7.29 & 20.66 & 19.73 & 20.20 \\
\hline $\mathrm{I}_{2} \times \mathrm{F}_{3}(0.70 \mathrm{ETC} \times 75 \% \mathrm{RD})$ & 6.21 & 6.22 & 6.22 & 17.65 & 16.80 & 17.23 \\
\hline $\mathrm{I}_{3} \mathrm{XF}_{1}(0.45 \mathrm{ETc} \times 125 \% \mathrm{RD})$ & 5.07 & 5.01 & 5.04 & 21.68 & 20.32 & 21.00 \\
\hline $\mathrm{I}_{3} \mathrm{KF}_{2}(0.45 \mathrm{ETC} \times 100 \% \mathrm{RD})$ & 3.95 & 3.89 & 3.92 & 16.89 & 15.79 & 16.34 \\
\hline $\mathrm{I}_{3} \mathrm{x} \mathrm{F}_{3}(0.45 \mathrm{ETc} \times 75 \% \mathrm{RD})$ & 3.28 & 3.23 & 3.26 & 14.02 & 13.08 & 13.55 \\
\hline
\end{tabular}

\section{Conclusion}

The experiments were conducted to know the influence of different irrigation levels, with fertigation levels on growth and yield of tomato. The results of the experiments were analyzed and following specific conclusions were derived. The yield of tomato is enhanced when cultivated in polyhouse compared to open field condition. The yield of tomato is more in polyhouse as compared to open field. The irrigations to the tomato should be scheduled daily $0.95 \mathrm{ETC}$ in polyhouse. The fertigation to the tomato should be scheduled alternate day $125 \% \mathrm{RD}$ in polyhouse.

Application of research: To study the yield response of tomato (Solanum lycopersicum L.) to different irrigation regimes and fertigation levels under polyhouse and open field conditions.

\section{Research Category: Irrigation Regimes and Fertigation}

\section{Abbreviations:}

RD: Recommended Dose

gm: Gram

Kg: Kilogram

Acknowledgement / Funding: Authors are thankful to Mahatma Phule Krish Vidyapeeth, Rahuri, Ahmednagar, 413722, Maharashtra

\section{*Principle Investigator: Dr S.D. Dahiwalkar}

University: Mahatma Phule Krishi Vidyapeeth, Rahuri, Ahmednagar, 413722, Maharashtra

Research project name or number: PhD Thesis

Author Contributions: All author equally contributed

Author statement: All authors read, reviewed, agree and approved the final manuscript

\section{Conflict of Interest: None declared}

Ethical approval: This article does not contain any studies with human participants or animals performed by any of the authors.

\section{References}

[1] Brahma S., Pankaj B., Luchon S. and Tridip H. (2009) Studies on response of tomato to different levels of $n$ and $k$ fertigation inside naturally ventilated polyhouse Assam Agricultural University, Jorhat-785013 1KVK,

[2] Cheema D.S., Kaur P. and Kaur S. (2004) Acta Horticulturae (ISHS), 659 , pp: $177-181$.

[3] Dunage V.S., Balakrishnan P. and Patil M.G. (2009) Karnataka J. Agric. Sci., 22(1), 133-136.

[4] Natarajan S., Sasikala S. and Kumaresan G.R. (2005) Influence of growing media, irrigation regime, nutrient management and mulching on growth, yield and economics of tomato under polyhouse condition. International Conference on Plasticulture and precision farming. Nov. 17-21, New Delhi. p. 51.

[5] Ramesh K.S. and Arumugam T. (2010) Mysore J. Agric. Sci., 44(4), $770-$ 776.

[6] Singh B. (2006) Protected Cultivation of Vegetable Crops. Kalyani publishers, New Delhi-110012. pp.58. 